\title{
SEA LEVEL CHANGES AND NEOTECTONICS: SOME EXAMPLES IN PORTUGAL (ARRÁBIDA AND SOUTHWEST)
}

\author{
ANA RAMOS-PEREIRA*
}

Resumo

A dinâmica litoral herdada é um tema recorrente na geomorfologia portuguesa. O reconhecimento dessa dinâmica passa pela identificação dos seus indicadores: formas de relevo e depósitos litorais correlativos, presentes nas áreas hoje emersas e submersas. À semelhança do que sucede presentemente, também no decurso do Quaternário, o litoral seria diversificado, com planícies arenosas com sistemas de praia-duna, sistemas de barreira, arribas com ou sem plataforma rochosa de sopé, estuários e terraços marinhos (elementos da plataforma litoral). Porém, esses indicadores nem sempre são de fácil identificação. No que respeita às formas de erosão - arribas com a respectiva sapa e plataforma rochosa de sopé - raramente se reconhecem, por serem formas antigas que foram sujeitas, desde a sua formação, à dinâmica geomorfológica, nomeadamente a movimentos de massa, desfigurando-as e dificultando a sua identificação. O estudo e enquadramento geomorfológico pormenorizado de muitos dos escarpados litorais, considerados previamente como arribas, tem revelado tratarem-se de escarpas de falha. No que respeita aos depósitos, (i) estes mudam lateralmente de fácies, (ii) as condições ambientais de génese dos depósitos quaternários mudaram e, em muitos casos, eles foram erodidos e/ou remexidos na sequência das variações da linha de costa que acompanham as flutuações do nível do mar e (iii) a actividade neotectónica, já reconhecida, pode tê-los mudado da sua posição original, fracturando-os, balançando-os ou mesmo levando à sua destruição. Por essas razões, as conclusões de um trabalho levado a efeito numa região não deverão ser extrapoladas, porque os vários compartimentos tectónicos no litoral não têm tido sempre o mesmo comportamento, como tm vindo a mostrar os diversos estudos precisos de pormenor recentemente divulgados. As correlações cronológicas são, também por isso, difíceis de estabelecer. Os dois casos apresentados permitem ilustrar a complexidade da dinâmica litoral, mas também as dificuldades de correlação e de extrapolação dos resultados, nomeadamente como consequência da actividade de neotectónico no litoral de Portugal continental.

Palavras - chave: indicadores litorais, flutuações do nível do mar, tectónica.

Abstract

* Centro de Estudos Geográficos da Universidade de Lisboa, Departamento de Geografia da Faculdade de Letras da U.L. E-mail: anarp@fl.ul.pt
The inherited coastal dynamics is a recurrent theme in Portuguese geomorphology. The recognition of this dynamics goes through the identification of its indicators: landforms and correlative coastal deposits, present in the present-day emerged and submerged areas. In comparison to what happens nowadays, also during the course of the Quaternary, the coast would have been diversified, with sandy plains with beach-dune systems, barrier systems, cliffs with or without rock platforms at their bottom, estuaries, and marine terraces (elements of the coastal platform). However, these indicators are not always easily identifiable. Relative to the types of erosion - cliffs with their notches and the rock platforms at the bottom - these are seldomly recognized, because of being ancient landforms that were subjected, since their creation, to geomorphologic dynamics, namely mass movements, damaging them and making difficult their identification. The detailed geomorphologic study and framework of many of the coastal escarpments, previously considered as cliffs, has shown them to be scarp faults. As to the deposits, (i) these change facies laterally, (ii) the environmental conditions in the genesis of the Quaternary deposits changed and, in many cases, they were eroded and/or remixed preceding the changes of the coastline that followed the sea level fluctuations and (iii) the already recognised neotectonic activity may have shifted them from their original position, fractured, tilted or even destroyed them. For these reasons, the conclusions from a study carried out in a region must not be extrapolated, because the different coastal tectonic sections do not always have the same behaviour, as have shown many recently published precise and detailed studies. The chronologic correlations are, therefore, difficult to establish. The two cases presented, allow show the complexity of the coastal dynamics, as well as the difficulty in correlating and extrapolating results, namely as a result of the activity of the coastal neotectonics of Portugal mainland.

Key - words: coastal indicators, sea level changes, tectonics. 


\section{INTRODUCTION}

In Portugal's mainland, the landscape is characterized by a heritage landform - the so-called coastal platform. This platform is related to relative sea level changes and its influence on coastal landforms and deposits (Fig. 1). The continuous flattened landform is slightly sloping towards the sea and can be found at different heights. Near Aveiro, the coastal platform is almost at sea level while, in other places of the western front, it can reach $150 \mathrm{~m}$ of altitude, showing several steps. Landward limit isn't always clear; however the regular presence of tectonic scarps makes the transition to continental relief often abrupt.

Coastal platform can be erosion or accumulation dominant (Fig. 1)1. In the first case, the razing took place independently of the local or regional lithostructural setting.

The continental shelf morphology is similar to the coastal platform (Fig. 1) and its western boundary is a structural one - the continental slope - in the transition from the continental to the marine lithosphere.

\section{THE SEA LEVEL CHANGE INDICATORS AND THE MAIN PROBLEMS TO ASSESS THEM}

The analysis of the nearly $940 \mathrm{~km}$ of Portuguese West and South coastline shows different sedimentary balance. Associated with Douro, Tejo and Guadiana Rivers, regions A1, A2, A4 and the Eastern sector of region B (Fig. 1) have a positive sedimentary balance in natural conditions (PEREIRA, 1992, 2004). On the contrary, regions A3 and A5 have a negative one. These regions are in the south side of two important morpho-tectonic structures, the Nazaré and Lisboa Canyons, which stop coastal drift sediment bypassing.

The present-day different coastal systems are related to the sediment supply from the main rivers and the longshore drift and its continuity (as well as human management of the coast and network dams). Its interruption is related to the two major faults that already existed over all the Quaternary. It means that, in the past, the coast was as diversified as today, with sandy plains with beach-dune systems, barrier systems, cliffs, with or without rock platforms at its bottom, estuaries, and marine terraces (elements of the coastal platform).

Landforms and sediments are the main indicators of sea level change. However: (i) correlative deposits locally change in facies as it happens today (from beach to dune sediments, for example); (ii) the genetic sediments environment of the Quaternary deposits has changed and they have been remixed and eroded by Pliocene and Quaternary shoreline fluctuations; (iii) the neoctectonic activity has been recognized in several places along the Portuguese coastal platform, destroying or tilting the main features and faulting sediments, so genesis generalizations are not to be made and sometimes chronological correlations are difficult to establish.

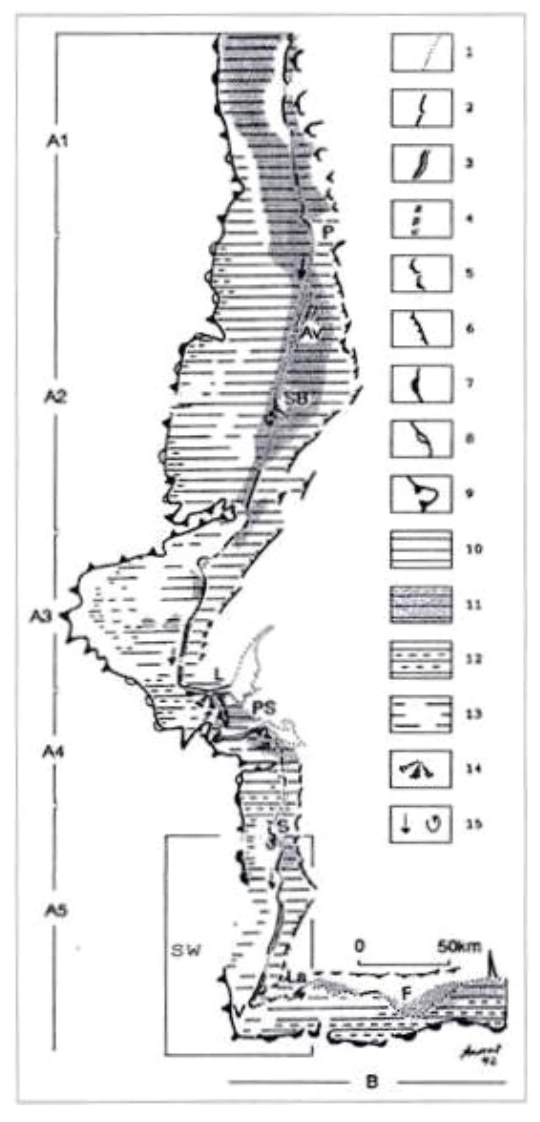

Fig. 1 - Coastal platform and continental shelf geomorphology.

1 - Sandy littoral; 2 - Cliff $<50 \mathrm{~m} ; 3$ - Cliff $>50 \mathrm{~m}$; 4 - Paleocliff; 5 - Erosion edge; 6 - Tectonic edge;

7 - Progradation edge; 8 - Aggradation edge;

9 - Regradation edge; 10 - Erosion dominant coastal platform and continental shelf; 11 - Accumulation dominant coastal platform and continental shelf; 12 - Progradation dominant continental shelf; 13 - Prominent relief's in 10; 14 - Profluvial delta; 15 - Coastal drift direction.

Av - Aveiro; F - Faro; La - Lagos; L - Lisboa; P - Porto; PS - Península de Setúbal; S - Sines; SB - Serra da Boa Viagem (after PEREIRA, 2004).

1 The expression coastal or littoral platform is use in a morphologic/physiographic sense and never in a genetic one. 
In what concerns the erosional landforms, the cliffs with notches and the rock platforms have been submitted to Quaternary evolution since they were generated, namely by mass movements, and their features are difficult to recognize. Another difficulty must be pointed out: most of the scarps between the coastal platform and the inland are considered to be scarp faults with Quaternary activity.

The chronological correlation between several deposits and landforms present along the coastal platform is not easy. The absence of recognized fauna or flora in Late Quaternary sediments is also a major problem. The lack of this kind of data can be the result of the incipient research carried out on this subject as well as the consequence of geochemical environment that can prevent its preservation.

\section{THE BALANCE BETWEEN TECTONIC AND SEA LEVEL CHANGES: TWO EXAMPLES}

\subsection{The Arrábida coast}

The Arrábida ridge, South of Lisbon, is a small limestone mountain uplifted, faulted and tilted during Quaternary. The south front is a complex structural feature. The major coastal landform is a cliff that can reach more than one hundred meters, with three steps related to sea level fluctuations, one of them submerged.

The highest level, at $40 \mathrm{~m}$, has no marine sediments and is covered by colluvial material. Below it, cliffs with a notch and a rock platform have been recognized. This one represents the most continuous level and is covered, in some places, by a discontinuous coarse sand beach deposit, sometimes with boulders (PEREIRA \& REGNAULD, 1994). This level shows the same trend as the mountain tectonic deformation, i. e., faulted and tilted to the West, from $10 \mathrm{~m}$ to $7 \mathrm{~m}$ above m.s.l. This episode is understood to be Eemian in age (Oxygen Isotopic Stage 5e) but no fauna were recorded. The beach deposit is covered by an aeolianite. The shells preserved in the beach deposit have been dated by ${ }^{14} \mathrm{C}$ and give an age of 36786 cal BP (32 $040 \pm 1410 / 1190 \mathrm{BP}), 36786 \mathrm{BP}$, is the position of the interception point of the calibration curve (PEREIRA \& ANGELUCCI, 2004). This date is related to a low sea level (about 30 to 45 meters below m.s.1.) when the coastline was about $4 \mathrm{~km}$ south from the present-day one. This marine level has several grottos, one of them (in the eastern sector) inhabited by Mousterian. The continental fauna recorded in the archaeological horizon showed a fresh coastal environment at about $30930 \pm 700$ BP: ICEN-387 (ANTUNES, 1991).
A lower level was recognized at $-7 \mathrm{~m}$ (Equipe ERLIDES, 1992), represented by a narrow discontinuous step, without dating elements. The authors proposed a probable age of 5000 years taking into account what was known in the continental shelf. This interpretation agrees with the new data and conclusions about rising sea level in the Sado estuary (PSUTY \& MOREIRA, 2000).

\subsection{The Southwest coast}

The major landforms are: the coastal platform bordered by small hills corresponding to a hemihorst in the northern middle half area and by several grabens developed N-S, in the southern area. The coastal platform has a complex genesis, both fluvial and marine (beach and dune environment), has been faulted, uplifted and locally downlifted since the Pliocene. Nine types of deposits were recognized: marine deposits, beach deposits, aeolian deposits (some of them carbonate) and alluvial fan deposits, from the Miocene to the Holocene (PEREIRA, 1990). Its evolution was highlighted in the area near Vila Nova de Milfontes, where 6 different deposits are better preserved (PEREIRA, 1990).

In this section, the platform is a well-preserved feature, no major river exists, exception made to the Mira River. However, this monotonous landform hides the leveled but faulted Paleozoic bedrock (Cambric schist and greywakes), where different types of deposits are still preserved (Fig. 2).

The detailed study of the morphology, the outcrops and the sedimentological analysis of the deposits and its lateral variations show:

(i) over the faulted bedrock, the Red Formation of Foro (FVF) or simply Red Formation, which is a sandstone formation, with a pebble layer at the bottom. The pebbles, and sometimes the boulders, are rounded as well as the sands that are also bright. These beach deposits change to a fluvial one and then to a red aeolinite inland at the bottom of Serra do Cercal (Fig. 3, log D6, D5, G2 and A1). The fluvial facies appears again at the top of the Serra, with iron-banded layers. The landscape was then a large alluvial plain near the sea, where the FVF was deposited. There was a sandy coastline with dunes and non-entrenched rivers drained the plain. At this time, the Serra do Cercal did not exist (Fig. 4.1-1);

(ii) an enormous change in the landscape was produced afterwards with the uplift of the Serra do Cercal. This tectonic episode is probably correlative of a climatic change because the plain was invaded by alluvial fans (LAI). Debris and mudflows were only episodic and locally reached the present day coastline; they are well preserved at the bottom slope and also inside the small valleys, near the scarp (Fig. 3, $\log$ D3 and D5); 


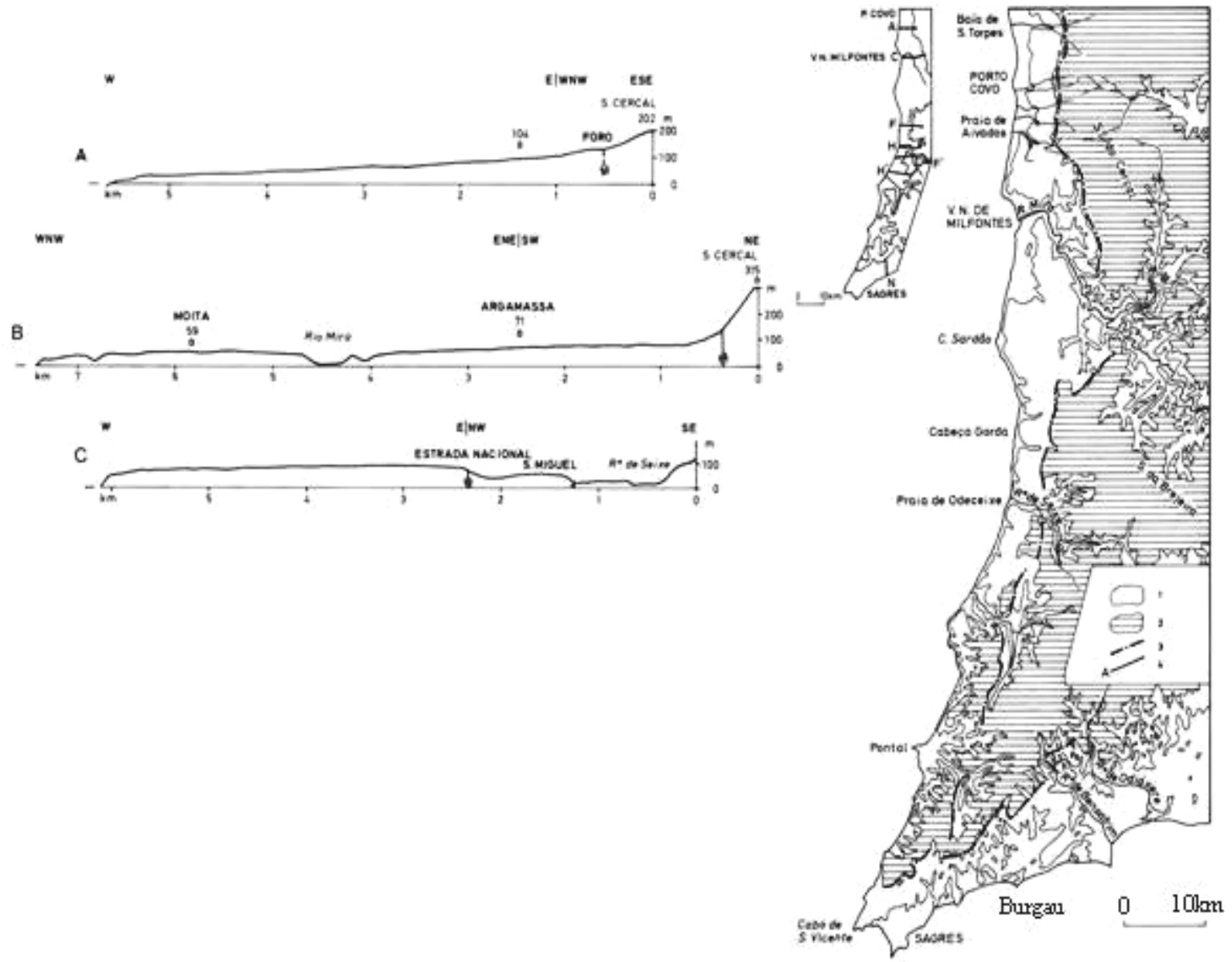

Fig. 2 - The Southwest of Portugal's mainland (PEREIRA, 1990). 1 - height $<100 \mathrm{~m} ; 2-i d$. > 100m;

3 -inland boundary of the littoral platform; 4 -transversal profiles of the littoral platform.

The deposits have a sandy-mud matrix and pebbles not only from the bedrock but also of the iron bands of the FVF (Fig. 4.1-2). During this episode, the socalled coastal platform was created;

(iii) the next episode registered in the platform was a marine invasion, leaving behind wellcalibrated sands, with marine shells and Fe-Mg sand layers. This deposit, the Aivados-Bugalheira Formation (FAB, Fig. 3, log G2 and D5) penetrates $11 \mathrm{~km}$ inland from the present day coastline in a subsided area, where the sea created a small bay (Fig. 4.2-3). In this area, this formation decreases in altitude from $50 \mathrm{~m}$ to present-day sea level in a stretch less than $10 \mathrm{~km}$ wide. These indications, as well as the visible liquefaction marks, suggest that they were submitted to tectonic strain;

(iv) a sea retreat allowed the establishment of small rivers, reworking the sands of FAB, as well as the aeolian mobilization. A big sand field - Malhão dune field ( $\mathrm{M}$ in Fig. 4.2-4) - cutting into the cliff today and penetrating $3 \mathrm{~km}$ inland was built up by $\mathrm{N}$ to WSW winds (it occupies $20 \mathrm{~km}^{2}$ today). This dune field is still preserved because it was stabilized by vegetation and then submitted to carbonation (Fig. 2, AdM in log G2 and D5). In the outcrops, the $\mathrm{CaCO}_{3}$ can reach $80 \%$ and is the result of dissolution of shells (there is no $\mathrm{CaCO}_{3}$ in the bedrock). The aeolianite of this dune field is also faulted near the sea and a scarp is still visible. The western tectonic compartment subsides and was invaded by the sea leaving a characteristic morphology of plateforme a vasques and sand and small rounded pebbles (Monte Figueira Formation);

(v) another sea retreat was registered and a new dune field - Aivados dune field, was built and then submitted to carbonation. Only the eastern leeward of the dune field is still preserved. It is cut into cliff, but it is still recognized in the internal continental shelf, where it creates islands, like the Pessegueiro Island (P in Fig.5). The dunes were built by NW to SW winds;

(vi) the latter evolution of the platform is related to the establishment of the drainage network and the transgressive dune field (Fig. 5). 

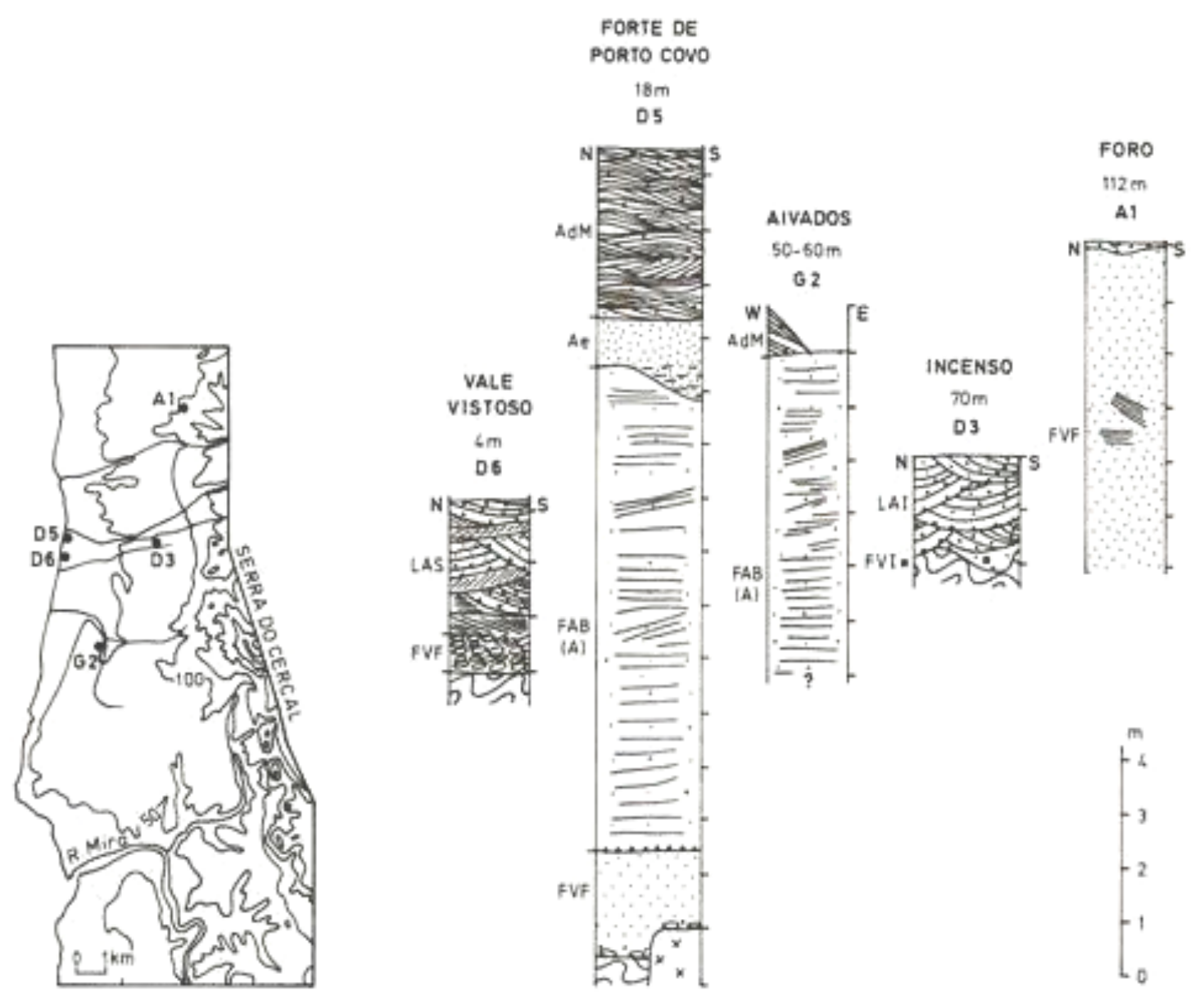

Fig. 3 - Logs of the deposits preserved on the littoral platform north of Vila Nova de Milfontes (PEREIRA, 1990).

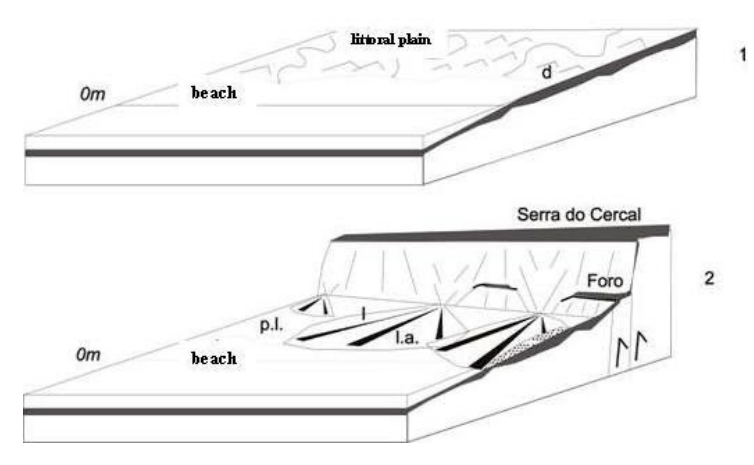

Fig. 4.1 - The evolution of the coastal platform dominated by Serra do Cercal during the Pleistocene (1) and the Plio-Quaternary transition (2) (PEREIRA, 1999).

1 - the littoral plain bathed by the sea, with beach and dunes (d); 2 - littoral gravel plain (p.1.), with alluvial fans (1.a.), bathed by the sea and dominated by Serra do Cercal. Legend in Fig. 5.

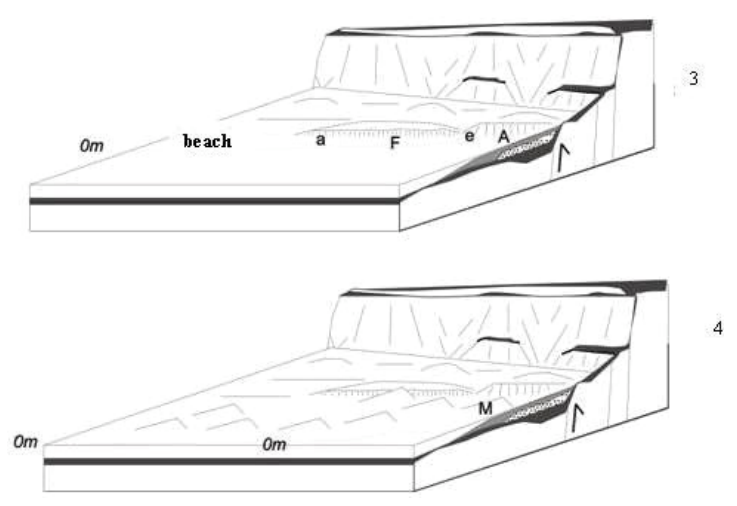

Fig. 4.2 - The evolution of the coastal platform dominated by Serra do Cercal during the Lower and Middle Pleistocene (?).

3 - e - scarp fault, a - cliff cut into the alluvial fans, A - Aivados, F - Fort). 4 - littoral platform covered by a large dune field (M - Malhão), after a sea retreat (PEREIRA, 2000). Legend in Fig. 5. 


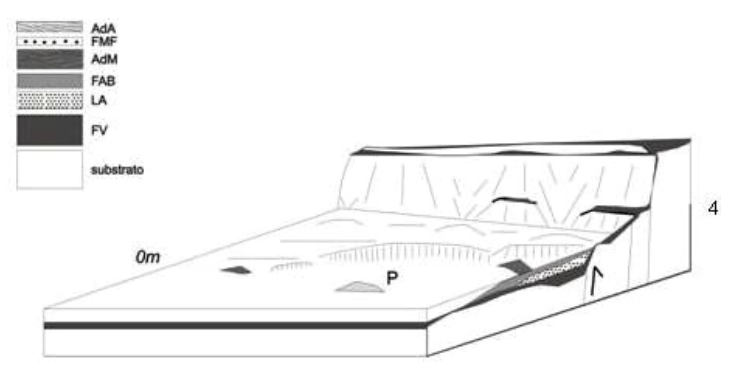

Fig. 5 - Present-day landscape. (PEREIRA, 1999). Deposits from the oldest to the youngest: FV - Red Formation (FVF); LA - alluvial fan; FAB - Aivados-Bugalheira Formation; AdM - Malhão aeolianite; AdA-Aivados aeolinite. (P - Pessegueiro Island).
In all the deposits mentioned before there are no fossils. After establishing the succession, several correlations have been made not only with this section of the coast but also inland and to the south. Pereira (1990) gives a Pliocene age to The Red Formation (Zanclian or Placencian), in relation to the establishment of the exoreic drainage network. The climate was probably warmer and wetter than in the present day, with contrasting seasons towards conditions of increasing dryness. The aridity increased more during the tectonic episode and the related alluvial fan. This episode took place in the transition between the Pliocene and the Quaternary. It can belong to the Ibero-Manchega II phase.

Therefore, the southwest coastal platform is the result of the morphotectonic differentiation of an old Tertiary surface. Table 1 synthesizes the latter sequence and the uncertainties.

Table 1 - Sequence of geomorphological episodes from the Lower Pleistocene to the Holocene (after PEREIRA, 1990 and PEREIRA \& ANGELluCi, 2004).

\begin{tabular}{|l|l|l|l|}
\hline Geomorphological feature & Sedimentological unit & Environment & Probable Age \\
\hline Aivados beach (old) & Aivados - Bugalheira Formation & Littoral - sandy coast & Lower Pleistocene? \\
\hline & $\begin{array}{l}\text { Fluvial rework of } \\
\text { Aivados - Bugalheira Formation }\end{array}$ & Fluvial & Middle Pleistocene? \\
\hline Malhão dune field & $\begin{array}{l}\text { (i) aeolian sand accumulation } \\
\text { (ii) vegetation settling } \\
\text { (iii) carbonation } \\
\text { (iv) Malhão aeolianite }\end{array}$ & Aeolian & $\begin{array}{l}\text { Middle Pleistocene } \\
\text { (OIS6?) }\end{array}$ \\
\hline $\begin{array}{l}\text { Monte Figueira } \\
\text { beach/rocky platform }\end{array}$ & $\begin{array}{l}\text { (i) Monte Figueira Formation } \\
\text { Malhão fault scarp }\end{array}$ & $\begin{array}{l}\text { Littoral-beach / rocky } \\
\text { platform }\end{array}$ & OIS 5 \\
\hline field and tilting of Monte Figueira rocky platform
\end{tabular}

(*) Calibrated data: $39490 \pm 2340$ BP (SCHROEDER-LANZ, 1971).

\section{FINAL REMARKS}

The cases presented give the example of the set of conditioning factors of inherited coastal features preservation (landforms and deposits) and the several changes that they can be submitted to. During Quaternary times, present-day coastal areas have changed from continental environment, namely fluvial and alluvial fan environment, to a coastal one, with different geomorphic agents like the sea and the wind and vice-versa. The sea and its level changes are the main forcing factor of coastal landforms, not only creating them but also destroying some of its previous creations.

The study of the Quaternary evolution of coastal geomorphology is like a puzzle that deserves to be made. 


\section{REFERENCES}

ANTUNES, M. Telles (1991). O Homem da gruta da Figueira Brava (ca 30 000BP), contexto ecológico, alimentação, canibalismo, Memórias da Academia das Ciências, Lisboa, Classe de Ciências, 31, pp. 487-538.

EQUIPE ERLIDES (1992). Découverte d'un niveau marin submergé le long de la chaîne de l'Arrábida, Portugal, Finisterra, 27 (53-54), pp. 183-186.

Pereira, A. Ramos (1990). A Plataforma Litoral do Alentejo e Algarve o Ocidental. Estudo de geomorfologia. PhD thesis, Faculdade de Letras, Universidade de Lisboa.

Pereira, A. RAmos (2000). A Geomorfologia e o ordenamento da costa alentejana, in G. Soares de Carvalho, F. Veloso Gomes \& F. Taveira Pinto (ed.) A Zona Costeira do Alentejo. Associação Eurocoast - Portugal, Porto, pp. 926.

Pereira, A. Ramos (1992). L'Homme et l'érosion: l'exemple $\mathrm{du}$ littoral portugais, Finisterra, 27 (53-54), Lisboa, pp. 205-225.
Pereira, A. Ramos \& Regnauld, H. (1994). Litorais quaternários (emersos e submersos) na extremidade sudoeste da Arrábida (Portugal), in A. Ramos Pereira et al. (eds.) Contribuições para a geomorfologia e dinâmicas litorais em Portugal. Centro de Estudos Geográficos, Linha de Acção de Geografia Física, 35, pp. 55-73.

Pereira, A. Ramos (2004). A faixa litoral, in M. Feio \& S. Daveau (eds.) O relevo de Portugal. Grandes unidades. Publicações da Associação Portuguesa de Geomorfólogos, vol.II. Coimbra, pp. 133-145.

Pereira, A. RAmos \& ANGelucci, D. (2004). Formações dunares no litoral português, do final do Plistocénico e inícios do Holocénico, como indicadores paleoclimáticos e paleogeográficos, in A.A. Tavares, M.J. Tavares \& J.L. Cardoso (eds.) Evolução Geohistórica da Litoral Português e Fenómenos Correlativos, Universidade Aberta, pp. 221-256.

PSUTY, N.P. \& MoreIRA, M.E. (2000). Holocene sedimentation and sea level rise in the Sado estuary, Journal of Coastal Researche, 18 (1), pp. 125-138.

SCHRÖDER-LANZ, H. (1971). Die ersren ${ }^{14} \mathrm{C}$ datierten Mittelwurmbildungen von der sudlichen Alentejokuste (Portugal), Eisszeitalter u. Gegenwart, 22, pp. 3-42. 